\title{
The Effectiveness of Reality Therapy for Decreasing Self-Motivation Problems of Lower Group Students
}

\author{
Mulawarman, S. Sunawan, Z.N. Amin \\ Universitas Negeri Semarang, Semarang, Indonesia \\ mulawarman@mail.unnes.ac.id
}

\begin{abstract}
The purpose this study is to investigate the effect of reality therapy on self-motivation problems. The design of this research is mix-methods. Two vocational high school students have involved the experiment based on the initial identification of the selection with purposive sampling techniques. Data were analyzed using descriptive statistics, non-parametric statistics Wilcoxon Test, and qualitative study with conversational analysis. The results showed that reality counseling effectively decreases self-motivation problems, while the results of the conversational analysis indicate that therapeutic changes occur in subject speech, want, and action, which oriented to reduce self-motivation problems. Even though there are some changes but they have not been planned specifically according to the needs of each subject. The results of this study clarify that reality therapy can be applied for helping high school students decreasing their self-motivation problems.
\end{abstract}

Keywords: Reality Therapy; Self-Motivation; Lower Groups Students

\section{INTRODUCTION}

According to the self-regulated learning theory, learning activity consistently relates to numerous aspects consisting cognitive, metacognitive, behavioral, motivational, and emotional/affective (Zimmerman \& Schunk, 2008; Zimmerman, 2011; Berger, 2011; Panadero, 2017).Selfregulated learners are not only distinguished by their proactive orientation and performance, but also by their motivation beliefs capabilities (Zimmerman, Bandura, and Martinez-Pons, 1992).

The level of effort, persistence, and focus on goal achievement are indicators of self-motivation beliefs, which has an important role for increasing academic success, quality of learning behavior, and performance (Effeney, Carrol, and Bahr, 2013). Zimmer-man (1998) explained that selfmotivation beliefs have several components, namely selfefficacy, outcome expectations, task value, and goal orientations.

Unfortunately, not all students have adequate selfmotivation beliefs (Evensen, Glenn \& Salisburry-Glennon, 2001). A study from Sunawan, Sugiharto, and Trianni (2012) indicated that students with learning difficulties conducted learning process in contrast with self-regulated learning principle. They had low self-efficacy, less task value, and unfocused learning orientations.
The results of other studies from Sugiharto and Sunawan (2011) specifically indicated the students learning problems related to self-motivation beliefs, namely: low-task commitment $(35.6 \%)$, non-effort attribution $(33.1 \%)$, and low self-efficacy $(30 \%)$. Therefore, the study which is oriented to increase student's self-motivation beliefs is important particularly by applying reality therapy in individual counseling services of school counseling context.

In this research, Reality therapy was employed because it can help and facilitate individuals to understand that in any difficult situation they always have hope (Corey, 2009). The awareness of hope is relevant with self-motivation beliefs, especially in aspect outcome expectations, self-efficacy, and goal orientations. Reality therapy principles may be helpful in explaining motivation, including self-motivation beliefs because these principles predict that students will pursue goals that are relevant to their personal wants and needs (Sunawan\&Xiong, 2016).

Reality counseling focuses on behavior and emphasizes the application of choice theory in developing an effective behavior (Wubbolding, 2005).Therefore, intervention for developing effective achievement goals can be carried out in concrete actions (Sunawan\&Xiong, 2016). Relevant to this concept and self-motivation beliefs can be developed in all individuals through self-control.

\section{METHOD}

\section{A. Procedure and Participant}

The current research used the mix-method with embedded design model. Creswell and Clark (2007) suggest that embedded design is a form of the mix-method where one data provide supporting data for other data. Procedures of this research began with collecting qualitative data of students' self-motivation. Next, conducting an experiment of pre-post one group design. Then, collecting and analyzing qualitative data after the intervention. Finally, interpreting the quantitative and qualitative findings. Procedures of the this research were shown in Figure 1.

The subjects of this research were two students from Public Vocational High School (SMKN) Pringapus, Semarang. They were purposively selected based on preliminary assessment results by using interviews and the 
learning difficulties inventory with the criteria of low selfmotivation beliefs.

\section{B. Instrument}

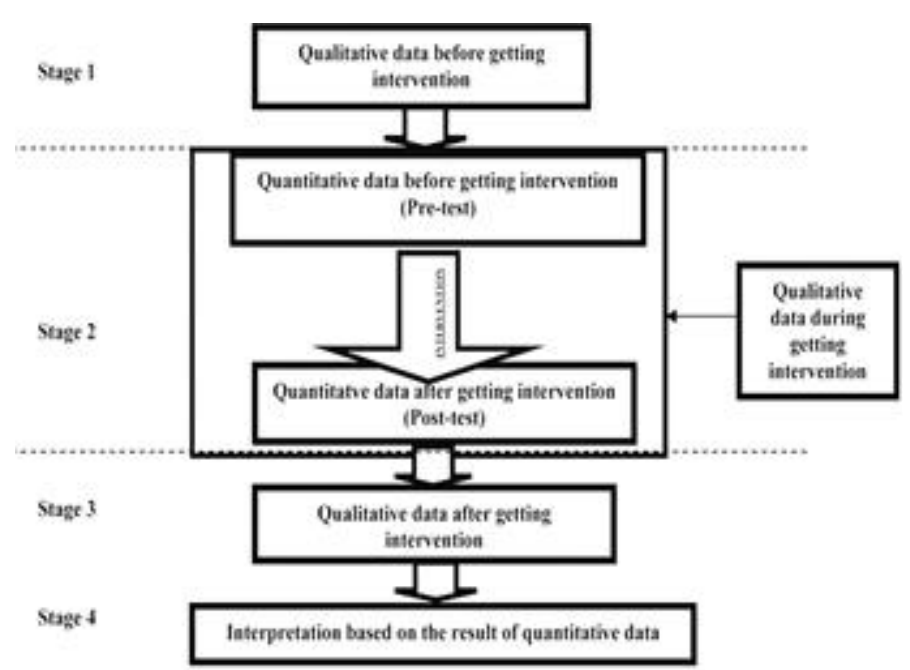

Fig. 1. Embedded experimental model (Creswell \& Clark, 2007)

Students' self-motivation problem was assessed using 21 items of the Learning Difficulties Inventory that is developed based on self-regulated learning theory (Sugiharto\&Sunawan, 2011). The reliability coefficient of the inventory is 0.68 . Moreover, the interview technique was also applied to get qualitative data and assess students' speeches about the failure experience, motivation, perception, and their efforts in the learning.

\section{Data Analysis}

Data were analyzed using descriptive statistics, nonparametric statistics Wilcoxon Test, and qualitative study with conversational analysis. Descriptive statistics were applied to identify the level of self-motivation problems, whereas nonparametric statistics of Wilcoxon Test was applied to determine the differences between pretest and posttest data. The conversation analysis is conducted to analyze counselees' speech and to identify the meaning and changing during counseling interview process.

\section{RESULT AND DISCUSSION}

\section{A. Result}

Two students were identified to have high self-motivation problems. Subject I marked 11 items that showed high selfmotivation problems, whereas subject II marked 9 items that expressed self-motivation problems at medium level.

After the counseling process within two sessions, posttest was given by using the learning difficulties inventory. The results of the intervention process (quantitative) can be seen in Table 1. Pretest and posttest data were analyzed with nonparametric Wilcoxon Test. The findings of this study showed that reality counseling significantly decreases self-motivation problems $(Z=1,857, \mathrm{p}$ (one-tailed)<0.05).

While the qualitative data through conversational analysis of counseling process shows the change of self-talk about selfmotivation beliefs toward responsible choices and selfplanning in a productive direction. Subject I was easily controlled by the environment and had a low commitment to be serious in learning. In the second session, subject I become an individual who was aware of the need for a positive change, tried to be diligent in school and motivated himself to take initiative in doing something in learning process.

Subject II in initial sessions was having less motivation to learn, prefer to play than study, and resistance of doing the learning task. If the subject has no desire to learn, he prefers to play. After second counseling session, subject II build awareness and willingness to change and to think about his future. Subjects see the opportunity to generate the motivation for learning.

Table 1 Pretest and Posttest results of Self-Motivation Beliefs (SMB) level after 2 times counseling session

\begin{tabular}{llllll}
\hline No & Subject & Pretest & $\begin{array}{l}\text { Level of } \\
\text { SMP }\end{array}$ & Posttest & $\begin{array}{l}\text { Level of } \\
\text { SMP }\end{array}$ \\
\hline 1 & Subject 1 & 11 & High & 5 & Low \\
2 & Subject 2 & 9 & Medium & 3 & Low \\
\hline
\end{tabular}

Note: SMP = self-motivation problems

Further analysis then was directed to combine the findings from pretest and posttest data as well as conversation analysis data as shown in Table 2. Based on the combined analysis, it can be concluded that the process of intervention using Reality Therapy has the effect of therapeutic changes. Those changes were reflected in subject speech, want, and action to make a solution of self-motivation beliefs problems.

\section{B. Discussion}

Based on the intervention results, the effectiveness of Reality therapy is in accordance with the common factors (Ottens and Klein, 2005). The effectiveness of therapy or counseling is determined by general therapeutic factors than specific therapeutic factors or techniques (Lambert, cited in Bertolino and O'Hanlon, 2002; Amin et al., 2016). These common factors include three factors: extra-therapeutic, therapeutic, and placebo or expectation factors. The largest contribution is extra-therapeutic factor that resulted as many as $40 \%$, followed by therapeutic relations factor at $30 \%$, and the expectation factor at $15 \%$, while the contribution of special therapeutic techniques is only at $15 \%$. 
TAble 2 Matrix of QuANTITATIVE Result (Statistical ANALysis) AND QUALITATIVE RESULTS (CONVERSATION ANALYSIS)

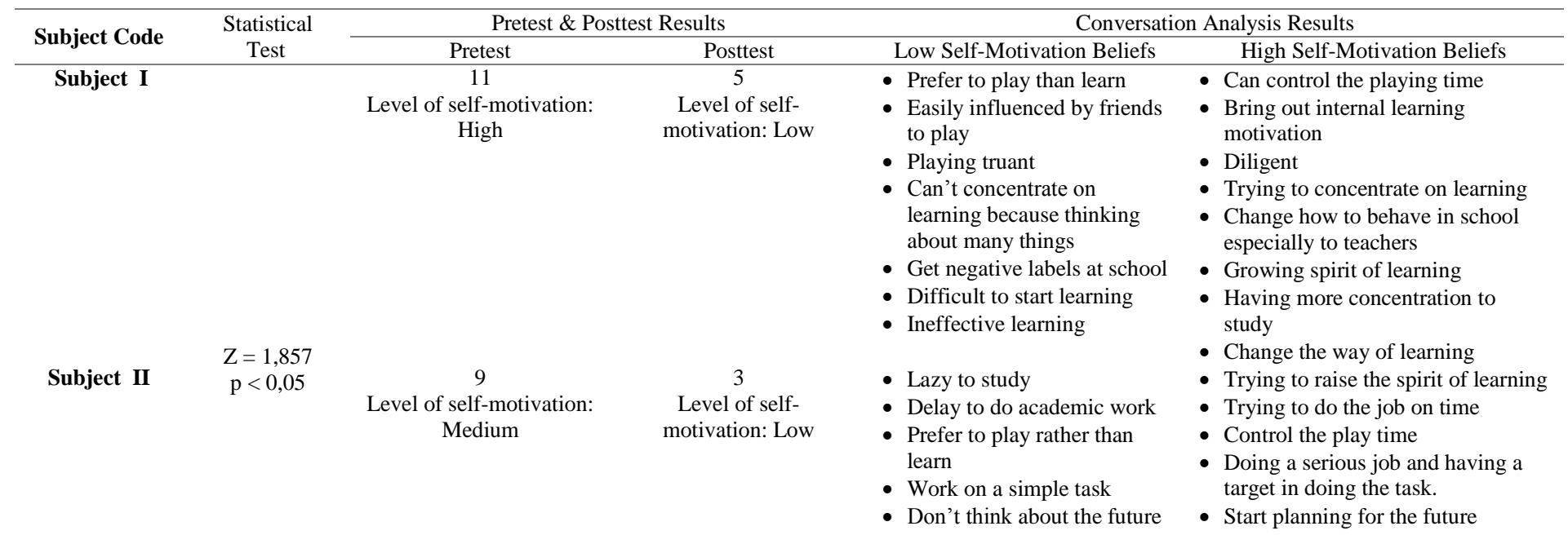

The behavior of subject's self-motivation beliefs is an implication of the choice of behavior whether to suffer or misery. The subjects choose to follow his sense of laziness (subject I and II), the subjects feel that it is a necessity that they fulfills tasks in order to avoid a more important need (carrying out academic tasks).

Glasser in Jones (2011) suggests that a person choose a form of self-destructive behavior to meet those needs rather than meeting other needs. In other words the behavior of selfmotivation beliefs is used so that the subject does not do anything, afraid to do something and want to get out of greater responsibility than what they previously did (Zimmerman, Bandura, and Martinez-Pons, 1992).

Through the process of therapy or counseling intervention, researchers invited subjects to assess their own behavior and to measure the desire of the subject, especially in case of generating the spirit of learning and doing academic tasks. In addition, interventions are also directed to seeking behavioral choices that lead to more effective and responsible behavioral performance.

Subjects become aware of their behavior, although have not completely changed the pattern of self-motivation beliefs. This issue according to Wubbolding (cited in Jones, 2011) occurs because the individual has not done self-study or thorough selfevaluation of his total behaviors that include thoughts, feelings actions or physiological.

\section{CONCLUSION}

This study finds that Reality therapy is effective to decrease self-motivation problems. The conversation analysis results showed that changes occur in subjects' speech, want, and action to make a solution on self-motivation beliefs looking planned in accordance with each counselee.

\section{REFERENCES}

[1] Amin, Z.N, Mulawarman, Nugraheni, E.P, and Carti. (2016). Counsellors' personal quality in public senior high school.

[2] Advances in Economics, Business and Management Research, 14, 444448.

[3] Berger, JL. (2011). Motivational beliefs and self-regulated learning in low vocational training track students. Journal of Educational and Development Psychology, 2(1), 37-48.

[4] Bertolino, B and O'Hanlon, B. (2002). Collaborative, competency-based: counseling and psychotherapy. Boston. Allyn and Bacon.

[5] Corey, G. (2009). Theory and Practice Counseling and Psychotherapy. Belmont: Brooks/Cole-Thomson Learning

[6] Creswell, J. W., \& Clark, V. L. P. (2007). Designing and Conducting Mixed Methods Research. California: Sage Publications Inc

[7] Eccles, J. S and Wigfield, A. (2002). Motivational Beliefs, Values, and Goals. Annual Reviews Psychology, 53, 109-132.

[8] Effeney, G, Carroll, A, and Bahr, N. (2013). Self-regulated learning: key strategies and their sources in a sample adolescent males. Australian Journal of Educational \& Development Psychology, 13, 58-74.

[9] Evensen, D.H., Glenn, J., \& Salisbury-Glennon, J.D. (2001). A qualitative study of six medical students in problem-based curriculum: toward a situated model of self-regulation, Journal of Educational Psychology, 93 (4), 659-676

[10] Jones, R.N. (2011). Theory and practice of counseling and therapy. London: Sage Publications.

[11] Ottens, A.J and Klein, J.F. 2005. Common factors: where the soul of counseling and psychotherapy resides. The Journal of Humanistic Counseling, 44(1), 32-45.

[12] Özkan, S. 2003. The roles of motivational beliefs and learning styles on tenth-grade students' biology achievement. Thesis. The graduate school of natural and applied sciences of the middle east technical university.

[13] Panadero, E. (2017). A review of self-regulated learning: six models and four directions for research.Journal Frontiers in Psychology.

[14] Sugiharto, D.Y.P and Sunawan. (2011).Pengembangan inventori kesulitasn belajar berbasis self regulated learning untuk sekolah menengah atas. Laporan Penelitian. Semarang: Universitas Negeri Semarang. 
[15] Sunawan and Xiong, J.. (2016). An application model of reality therapy to develop effective achievement goals in tier three intervention. International Education Studies, 9 (10), 16-26.

[16] Sunawan, Sugiharto, D.Y.P, \&Trianni. (2012). Bimbingan kesulitan belajar berbasis self regulated learning untuk meningkatkan prestasi belajar siswa. Jurnal Ilmu Pendidikan, 18(1), 113-124

[17] Sunawan. 2005. Beberapa bentuk perilaku underachievement dari perspektif teori self regulated learning. Jurnal Ilmu Pendidikan. Vol. 12(2), 128-142.

[18] Wubbolding, R.E. 1995. Reality therapy theory. In Capuzzi, D., \& Gross, D.R. Counseling and psychotherapy:theories and interventions. Upper Saddle River: Merrill Prentice Hall
[19] Zimmerman, B. J. 2011. Motivational sources and outcomes of selfregulated learning and performance. In B. J. Zimmerman, \& D. H. Schunk (Eds.) Handbook of self-regulation of learning and performance (pp. 49-64). New York, NY: Routledge.

[20] Zimmerman, B. J., \& Schunk, D. H. 2008. Motivation: An essential dimension of self-regulated learning. In B. J. Zimmerman, D. H. Schunk, (Eds.), Motivation and self-regulated learning: Theory, research and applications (pp. 1-30). New York: Lawrence Erlbaum Associates

[21] Zimmerman, B.J, Bandura, A, and Martinez-Pons, M. 1992. Selfmotivation for academic attainment: the role of self-efficacy beliefs and personal goal setting. American Educational Research Journal, 29 (3), 663-676. 